\title{
Pengaruh Kualitas Kehidupan Kerja terhadap Perilaku Kerja Inovatif dengan Di mediasi Komitmen Organisasi Pada Karyawan
}

\author{
MUHAMMAD RIO BAGUS ILMAWAN \& FAJRIANTHI* \\ Fakultas Psikologi Universitas Airlangga
}

\begin{abstract}
ABSTRAK
Penelitian ini bertujuan untuk mengetahui pengaruh kualitas kehidupan kerja terhadap perilaku kerja inovatif dengan komitmen organisasi sebagai variabel mediasi pada karyawan. Menggunakan metode kuantitatif melalui survei pada 130 karyawan yang berdomisili di Provinsi Jawa Timur. Alat ukur dalam penelitian ini adalah Innovative Work Behavior Scale Kleysen \& Street, TCM Employee Commitment Survey Meyer \& Allen dan Quality of Working Life scale Wayne. Komitmen organisasi akan dianalisis melalui affective organizational commitment, continuance organizational commitment dan normative organizational commitment. Analisis data dilakukan dengan bantuan SPSS 22.0 for Windows. Hasil penelitian menyimpulkan adanya peran partial mediation komitmen organisasi yang secara tidak langsung mengendalikan pengaruh kualitas kehidupan kerja terhadap perilaku kerja inovatif. Sehingga kualitas kehidupan kerja karyawan dapat memprediksi perilaku kerja inovatif dengan di mediasi oleh AC, CC dan NC. Tingginya kualitas kehidupan kerja akan meningkatkan komitmen organisasi, yang kemudian meningkatkan perilaku kerja inovatif pada karyawan.
\end{abstract}

Kata kunci: karyawan, kualitas kehidupan kerja, komitmen organisasi, perilaku kerja inovatif

\begin{abstract}
This study to determine effect of quality of work life on innovative work behavior with organizational commitment as mediating variable for employees. Quantitative methods through a survey of 130 employees who live in Province of East Java. Measuring instruments in this study are Innovative Work Behavior Scale Kleysen \& Street, TCM Employee Commitment Survey Meyer \& Allen and QWL scale Wayne. In this study organizational commitment will be analyzed through the affective organizational commitment, continuance organizational commitment and normative organizational commitment. Data analysis with SPSS 22.0. The result of the reaseach that a role of partial mediation in organizational commitment which indirectly controlled the influence of the quality of work life on innovative work behavior. So quality of work life of employees can predict innovative work behavior mediated by AC, CC and NC. High quality of work life will increase organizational commitment than can increases innovative work behavior to, among employees.
\end{abstract}

Keywords: employees, innovative work behavior, organizational commitment, quality of working life

Buletin Penelitian Psikologi dan Kesehatan Mental (BRPKM), 2021, Vol. 1(1), 541-550

*Alamat korespondensi: Fakultas Psikologi Universitas Airlangga, Kampus B Universitas Airlangga Jalan

Airlangga 4-6 Surabaya 60286. Surel: fajrianthi@psikologi.unair.ac.id 


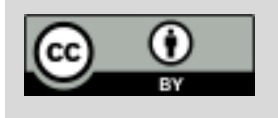

Naskah ini merupakan naskah dengan akses terbuka dibawah ketentuan the Creative Common Attribution License (CC-BY-4.0) (http://creativecommons.org/licenses/by/4.0), sehingga penggunaan, distribusi, reproduksi dalam media apapun atas artikel ini tidak dibatasi, selama sumber aslinya disitir dengan baik.

\section{PEN D A H U L U A N}

Setiap organisasi akan melakukan upaya optimalisasi pemanfaatan sumber daya manusia yang dimiliki untuk mengikuti perubahan organisasi menuju era pembaruan sains dan teknologi. Hal tersebut akan ditemui pada segala bidang usaha demi kebutuhan peradaban manusia itu sendiri. Saat ini, kita hidup di dunia yang semakin sederhana, cepat, besar, jelas, dan baik karena adanya inovasi, Sehingga organisasi dituntut untuk menyadari bahwa membuat proses, produk, dan prosedur yang baru merupakan hal yang sangat penting untuk pertumbuhan dan produktivitas organisasi di segala sektor.

Segala upaya yang dilakukan oleh individu atau perusahaan untuk mengembangkan atau memberi warna baru untuk produk dan cara atau ide yang telah ada sebelumnya dikenal sebagai inovasi (Yuan \& Woodman, 2010 dalam Korzilius dkk, 2017). Hal tersebut dibuktikan dengan mempertimbangkan laporan dari Boston Consulting Group pada tahun 2015 menyatakan bahwa sebanyak 79\% perusahaan menjadikan inovasi sebagai agenda prioritas utamanya, dimana menandakan pentingnya inovasi pada perusahaan. Sementara itu di Indonesia sendiri indeks inovasi cenderung fluktuatif dengan angka 29,7 pada tahun 2019 yang mana berada pada peringkat kedua terbawah di kawasan Asia Tenggara, 2016 mendapat indeks paling rendah di angka 29,1, 2017 dengan 30,1, 2018 29,8 dan pada tahun 2020 berada di peringkat 4 dari bawah meskipun dengan nilainya rendah 26,5.

Inovasi dalam perusahaan sendiri dapat dilakukan dengan melibatkan karyawan yang kompeten di bidangnya untuk memunculkan perilaku kerja inovatif. Perilaku kerja inovatif adalah keseluruhan dari tindakan individu yang mengarahkan pada pemunculan, pengenalan dan penerapan dari sesuatu baru yang dapat menguntungkan pribadi, kelompok maupun organisasi yang mana berbentuk pengembangan ide atau teknologi baru yang lebih efisien (Kleysen \& Street, 2001). Perilaku kerja inovatif merupakan sebuah bagian dari pengembangan perusahaan yang berbeda dengan kreativitas karyawan, namun masih saling terkait. Kreativitas merupakan proses individu berpikir untuk mendapatkan jalan alternatif dalam menyelesaikan suatu tujuan dan perilaku kerja inovasi merupakan implementasi ide kreatif baik secara individu maupun kelompok dengan pengaruh positif yang menyeluruh bagi perusahaan (West, 2002 dalam De Jong \& Den Hartog, 2010).

Dalam pelaksanaan dari perilaku inovatif memerlukan tahapan yang terbagi dalam 4 dimensi, yaitu opportunity exploration yaitu pemanfaatan kesempatan sebagai pemicu dalam menciptakan alternatif baru mengenai proses kerja, produk atau pelayanan, Idea generation merupakan pengolahan kembali informasi dan konsep yang telah dibuat, championing merupakan perilaku untuk mencari dukungan dan membangun koalisi untuk melibatkan pihak lain dalam inovasi, dan dimensi yang terakhir adalah Application merupakan proses untuk mengevaluasi dan mengaplikasikan ide dalam tindakan nyata (De Jong \& Den Hartog, 2010).

Untuk memunculkan perilaku karyawan dalam melakukan inovasi dapat dipengaruhi oleh banyak faktor, secara umum dapat dikelompokkan menjadi 2 faktor utama, yaitu internal dan eksternal, faktor internal meliputi keberagaman demografi, perilaku proaktif, self-leadership, self efficacy . Sedangkan faktor eksternal meliputi gaya kepemimpinan, struktur organisasi, memori organisasi (Octavia \& Ratnaningsih, 2017). Dan pada penelitian ini akan berfokus pada dua faktor yaitu faktor kualitas 
kehidupan kerja karyawan (Warhurst dkk., 2017) dan komitmen organisasi (De Jong \& Den Hartog, 2010).

Quality of working life atau dalam bahasa Indonesia berarti kualitas kehidupan kerja merupakan persepsi karyawan bahwa mereka ingin merasa aman, secara relatif merasa puas dan mendapat kesempatan mampu tumbuh dan berkembang selayaknya manusia (Wayne, 1992 dalam Arifin, 2001). Sementara itu komitmen organisasi sendiri yaitu suatu konstruk psikologis yang berupa karakteristik hubungan anggota organisasi dengan organisasinya, dan memiliki implikasi terhadap keputusan individu untuk melanjutkan keanggotaannya dalam berorganisasi, peranan komitmen organisasi dapat meningkatkan efektifitas dalam bekerja, sehingga atribut tersebut merupakan salah satu hal yang cukup penting di perusahaan (Allen \& Meyer, 1996).

Quality of working life pada penelitian ini akan berperan sebagai variabel prediktor dengan komitmen organisasi sebagai variabel mediasi, dengan penambahan komitmen organisasi dalam penelitian ini untuk menjembatani hubungan tidak langsung (indirect effect) antara variabel bebas dan variabel tergantung. Menurut Baron \& Kenny (1986) menyebutkan bahwa hubungan antar variabel tersebut akan lebih optimal ketika porsi dari hubungan tidak langsung lebih besar daripada peranan langsung. Nantinya proses analisis pengaruh mediasi yang dilakukan pada penelitian ini bertujuan untuk menjawab peranan mediasi yang terjadi antara partial mediation dan full mediation.

Penelitian ini akan menggunakan subjek karyawan yang bekerja pada organsasi/instansi/perusahaan, dengan speisifikasi penelitian berupa analisis yang digunakan untuk mewakili komitmen organisasi menggunakan ketiga dimensi dari komitmen organisasi yaitu affective organizational commitment, continuance organizational commitment dan normative organizational commitment. Hal tersebut dikarenakan pada teori komitmen organisasi yang dikemukakan oleh Meyer \& Allen multidimensional yang tidak dapat disatukan.

Berdasarkan uraian permasalahan diatas dan saran dari penelitian terdahulu, peneliti akan menguji apakah dengan quality of working life yang tinggi akan meningkatkan perilaku kerja inovatif juga melalui jalur mediasi oleh variabel komitmen organisasi. Setelah melalui proses analisa nantinya dalam penelitian dimungkinkan menghasilkan pengaruh tertentu dalam tiap variabelnya. Dengan adanya penelitian ini diharapkan dapat dijadikan patokan dalam kegiatan evaluasi untuk menentukan perbaikan kualitas kerja melalui kegiatan inovasi dan dapat dilihat melalui bagaimana komitmen karyawan dan kualitas kehidupan kerja sehingga akan berpengaruh pada peningkatan produktivitas kerja dan membantu pihak pengelola sumber daya manusia dalam menyusun formulasi yang ideal dari kualitas kehidupan kerja dan komitmen organisasi untuk meningkatkan inovasi pada perusahaan. Adapun hipotesis dari penelitian ini adalah :

$\mathrm{H}_{1}$ : Quality of working life berpengaruh terhadap perilaku kerja inovatif

$\mathrm{H}_{2}$ : Quality of working life berpengaruh terhadap komitmen organisasi

$\mathrm{H}_{3}$ : Komitmen organisasi berpengaruh terhadap perilaku kerja inovatif

$\mathrm{H}_{4}$ : Quality of working life berpengaruh terhadap perilaku kerja inovatif dengan menggunakan komitmen organisasi sebagai variabel mediasi. 


\section{Desain Penelitian}

\section{E T O D E}

Tipe penelitian yang digunakan adalah kuantitatif. Penelitian kuantitatif merupakan metode penelitian yang menggunakan data dalam bentuk angka yang kemudian data-data numerikal tersebut diolah dengan menggunakan statistik invalid source specified. Data diperoleh dengan teknik survei yang dilakukan dengan menyebarkan kuesioner tertulis pada sejumlah subjek, tanpa ada pengkondisian terhadap subjek (Neuman, 2006).

\section{Partisipan}

Pada penelitian ini, partisipan yang menjadi subjek penelitian yaitu karyawan yang bekerja di wilayah Provinsi Jawa Timur. Dengan teknik non probabilty sampling yang berjenis purposive sampling. Teknik ini dipilih karena memiliki alasan diantaranya kasus yang diteliti memiliki kekhasan tersendiri, partisipan yang sulit dijangkau atau memiliki populasi khusus dan ingin meneliti kasus secara mendalam dengan tujuan pemahaman yang mendalam pula, bukan menggeneralisasi suatu populasi. Jumlah partisipan dari penelitian ini adalah 130. ( $\mathrm{M}_{\mathrm{usia}}=25,93 ; 58$ persen perempuan). Mayoritas usia partisipan paling banyak 21-25 tahun (63\%). Mayortitas masa kerja partisipan paling banyak dibawah 2 tahun $(55,4 \%)$.

\section{Pengukuran}

Pada penelitian ini menggunakan 3 alat ukur yang digunakan dalam penelitian ini Innovative Work Behavior Scale milik Kleysen \& Street, (2001) untuk mengukur perilaku kerja inovatif yang memiliki reliabilitas $(\alpha=.928)$, TCM Employee Commitment Survey Meyer dan Allen yang telah ditranslasi oleh Natasha (2017) untuk mengukur komitmen organisasi yang memiliki reliabilitas $(\alpha=.889)$ dan Quality of Working Life scale Wayne, (1992 dalam Arifin, 2001) yang telah diadaptasi oleh (Ariani, 2017) untuk mengukur quality of working life yang memiliki reliabilitas $(\alpha=.890)$. Semua alat ukur tersebut menggunakan skala likert 5 jenjang dengan pilihan sangat tidak setuju hingga sangat setuju (1="sangat tidak setuju", 5="sangat setuju"). Semua alat ukur telah dilakukan uji validasi dengan masing masing menggunakan content validity dengan melibatkan expert judgement pada alat ukur komitmen organisasi dan perilaku kerja inovatif sementara alat ukur quality of workig life menggunakan criterion validity dengan mempertimbangkan nilai korelasi bivariate pada masing-masing indikator dengan total skor konstruk.

\section{Analisis Data}

Teknik analisis pada penelitian ini adalah regresi linear sederhana, regresi linear berganda dan uji mediasi menggunakan PROCESS oleh Andrew F. Hayes. Sebelum melakukan pengujian hipotesis diperlukan uji asumsi terlebih dahulu berupa uji normalitas dimana one-sample kolmogorov_smirnov tets menunjukan signifikansi lebih dari 0,05, selanjutnya uji linearitas yang menghasilkan signifikan dibawah 0,05 yang bermakna linier diantara variabelnya dan uji asumsi yang terakhir dilakukan uji homokedastisitas, dari uji tersebut scatterplot tidak mengalami heterokedastisitas. Setelah melakukan uji asumsi akan dilakukan uji hipotesis, dimana dalam penelitian ini seluruh pengujian dilakukan dengan bantuan IBM SPSS Statistic 22 for Windows. 


\section{HAS I L P EN EL I T I A N}

Hasil dari uji analisis deskriptif menunjukan jumlah partisipan sebanyak 130 menghasilkan skor terendah (Min) pada variabel quality of working life sebesar 18, variabel komitmen organisasi sebesar 50 dan variabel perilaku kerja inovatif sebesar 40. Skor tertinggi (Max) pada variabel quality of working life sebesar 45, variabel komitmen organisasi sebesar 90 dan variabel perilaku kerja inovatif sebesar 70 . Nilai rata-rata (Mean) pada variabel quality of working life sebesar 36,86, variabel komitmen organisasi sebesar 66,10 dan variabel perilaku kerja inovatif sebesar 58,72. Berdasarkan data yang didapatkan, sebanyak 83 (64\%) partisipan memiliki tingkat quality of working life pada kategori sedang, dengan 29 (22\%) berada pada kategori rendah sementara sisanya dalam kategori tinggi. Terdapat 77 (59\%) partisipan yang tergolong dalam kategori sedang pada nilai komitmen organisasi, pada kategori rendah dan tinggi masing-masing 29 (22\%) dan 24 (18\%). Pada variabel perilaku kerja inovatif sebanyak 79 (61\%) pada kategori sedang, 29(22\%) pada kategori tinggi dan sisanya $22(17 \%)$ berada pada kategori rendah. Dalam pengkategorian tersebut sesuai dengan rumus yang ada pada Azwar (2012).

Hasil uji regresi linear sederhana antara quality of working life terhadap perilaku kerja inovatif menghasilkan nilai signifikansi 0,00 dengan $R$ Square sebesar 0,276, dengan hasil tersebut maka berpengaruh poisitif dan signifikan sebesar $27,6 \%$. Pada uji regresi linear antara quality of working life terhadap ketiga dimensi dari komitmen organisasi organisasi yaitu affective organizational commitment $(A C)$, continuance organizational commitment (CC) dan normative organizational commitment (NC) menghasilkan signifikansi dibawah 0,05 dan masing-masing memiliki pengaruh sebesar 16,8\%, 28,3\% dan $34,3 \%$. Uji selanjutnya adalah uji regresi berganda antara ketiga dimensi dari komitmen organisasi organisasi yaitu affective organizational commitment (AC), continuance organizational commitment (CC) dan normative organizational commitment (NC) terhadap perilaku kerja inovatif yang menghasilkan signifikansi sebesar 0,000 dan nilai pengaruh sebesar 30,9\%. Selanjutnya adalah melakukan uji mediasi PROCESS by Andrew F. Hayes yang diperankan oleh komitmen organisasi pada pengaruh quality of working life terhadap perilaku kerja inovatif dimana terjadi partial mediation, dengan nilai efek sebesar 0,32 .

Selain itu dilakukan juga analisis jalur untuk menentukan besaran koefisien dan pengaruh mediasi yang terjadi, dimana pada jalur a menunjukkan koefisien 0,5450 dan taraf $p<0,05(0,000<0,05)$ yang berarti QWL berpengaruh positif dan signifikan terhadap perilaku kerja inovatif, koefisien 0,2732 taraf $p<0,05$ $(0,000<0,05)$ pada jalur pertama yang berarti QWL berpengaruh positif dan signifikan terhadap affective organizational commitment (AC), jalur selanjutnya menunjukkan koefisien 0,5450 dan taraf $\mathrm{p}<0,05(0,000<0,05)$ yang berarti $\mathrm{QWL}$ berpengaruh positif dan signifikan terhadap continuance organizational commitment (CC), pada jalur selanjutnya menunjukkan koefisien 0,4144 dan taraf $\mathrm{p}<0,05(0,000<0,05)$ yang berarti QWL berpengaruh positif dan signifikan terhadap normative organizational commitment (NC) dan pada jalur selanjutnya menunjukkan koefisien 0,6833 dan taraf $\mathrm{p}<0,05(0,000<0,05)$ yang berarti normative organizational commitment $(N C)$ berpengaruh positif dan signifikan terhadap perilaku kerja inovatif. Sementara itu jalur a' menunjukkan koefisien 0,2284 dan taraf $p>0,05(0,0567<0,05)$ yang berarti QWL berpengaruh positif dan tidak signifikan terhadap perilaku kerja inovatif, jalur selanjutnya menunjukkan koefisien 0,3245 dan taraf $p>0,05(0,0583<0,05)$ yang berarti affective organizational commitment berpengaruh positif dan tidak signifikan terhadap perilaku kerja inovatif dan jalur yang terakhir adalah menunjukkan koefisien $-0,1432$ dan taraf $\mathrm{p}>0,05$ $(0,4051<0,05)$ yang berarti continuance organizational commitment berpengaruh negatif dan tidak signifikan terhadap perilaku kerja inovatif. 


\section{I S K U S I}

Pada penelitian ini yang bertujuan untuk mengetahui pengaruh quality of working life terhadap perilaku kerja inovatif dengan melibatkan komitmen organisasi sebagai variabel mediasi pada karyawan. Dari uji yang telah dilakukan menghasilkan bahwa antara QWL terhadap perilaku kerja inovatif memiliki pengaruh positif dan signifikan, antara QWL terhadap komitmen organisasi memiliki pengaruh positif dan signifikan, antara komitmen organisasi terhadap perilaku kerja inovatif memiliki pengaruh positif dan signifikan, terdapat partial mediation yang diperankan oleh komitmen organisasi pada pengaruh QWL terhadap perilaku kerja inovatif.

Berdasarkan hasil uji regresi linier yang pertama untuk menguji pengaruh antara QWL terhadap perilaku kerja inovatif. Diperoleh nilai signifikansi $<0,05(0,000<0,05)$. Hasil tersebut menunjukkan bahwa QWL memiliki pengaruh signifikan terhadap perilaku kerja inovatif pada karyawan. Sumbangan pengaruh yang diberikan QWL terhadap perilaku kerja inovatif pada karyawan sebesar 27,6\% dan 72,4\% lainnya dipengaruhi oleh faktor lain yang tidak diteliti dalam penelitian ini.

Dari hasil uji tersebut diperoleh persamaan garis yang akan memperlihatkan dinamika pengaruh QWL terhadap perilaku kerja inovatif pada karyawan. Persamaan garis yang dihasilkan adalah $\mathrm{Y}=38,632+$ 0,545X. Dari persamaan tersebut, terdapat tanda (+) yang menandakan adanya pengaruh positif, sehingga dapat diartikan bahwa jika nilai QWL meningkat, maka perilaku kerja inovatif akan meningkat juga. Berdasarkan nilai signifikansi uji regresi linear sederhana dan persamaan garis, dapat disimpulkan bahwa QWL memiliki pengaruh terhadap perilaku kerja inovatif yang bersifat positif. Artinya, saat seorang karyawan memiliki QWL yang tinggi, maka perilaku mereka untuk berinovasi akan meningkat. Hasil penelitian ini dapat memperkuat penelitian oleh Elshifa dkk., (2020) yang menyatakan bahwa semakin tinggi QWL pada karyawan maka akan memunculkan perilaku kerja inovatif, sebaliknya jika memiliki QWL rendah maka akan memiliki perilaku kerja inovatif yang rendah juga. Selain itu penelitian ini juga mendukung Abstein dkk., (2014) dimana karyawan yang terjamin QWL-nya akan mampu menciptakan cara-cara baru untuk mencapai tujuannya dan akan meningkatkan efektifitas dan efisiensi tugasnya.

Pada penelitian ini juga melakukan pengujian regresi linear antara QWL terhadap ketiga dimensi dari komitmen organisasi yaitu affective organizational commitment, continuance organizational commitment dan normative organizational commitment. Diperoleh nilai signifikansi $<0,05(0,000,0,000$ dan $0,001<0,05)$. Hasil tersebut menunjukkan bahwa QWL memiliki pengaruh signifikan terhadap affective organizational commitment, continuance organizational commitment dan normative organizational commitment (komitmen organisasi) pada karyawan. Sumbangan pengaruh yang diberikan QWL terhadap affective organizational commitment pada karyawan sebesar 16,8\% dan 83,2\% lainnya merupakan faktor lain, pengaruh yang diberikan QWL terhadap continuance organizational commitment sebesar 28,3\% dan 71,7\% lainya merupakan faktor lain dan pengaruh yang diberikan QWL terhadap normative organizational commitment adalah sebesar 34,3\% dan 65,7\% lainnya faktor lain yang tidak diteliti pada penelitian ini. Pada temuan hasil analisis jalur juga dapat memberikan penjelasan terkait peranan mediasi yang terjadi adalah partial mediation akibat terjadi pengaruh yang signifikan antara peranan langsung dan tidak langsung.

Penelitian tersebut mendukung penelitian dari Nurcholisyah (2007) yang menyatakan bahwa terdapat adanya korelasi positif dan signifikan antara QWL terhadap affective organizational commitment $(A C)$, continuance organizational commitment (CC) dan normative organizational commitment (NC) yang merupakan dimensi dari komitmen organisasi pada karyawan. Dimana semakin tinggi QWL karyawan maka semakin tinggi pula affective organizational commitment $(A C)$, continuance organizational commitment (CC) dan normative organizational commitment (NC) yang dihasilkan oleh karyawan. 
Hasil analisis tersebut juga mendukung penelitian Syafrudin (2013), Parvar dkk. (2013) dan Varma, Aparna J., Kotresh Patil, (2018) dan Zin, (2004) dalam penelitiannya menyebutkan bahwa kunci utama dalam komitmen adalah bagaimana perusahaan dapat mengutamakan nilai-nilai dasar dalam proses kualitas kehidupan kerjanya, dimana beberapa perusahaan telah memasukkan kualitas kehidupan kerja sebagai budaya dalam perusahaan. Bahwa keberhasilan penerapan kualitas kehidupan kerja pada karyawan secara menyeluruh akan berdampak positif terhadap komitmen organisasi karyawan, dimana semakin tinggi kualitas kehidupan kerja akan memunculkan komitmen organisasi dan kemudian karyawan akan melakukan pekerjaannya lebih efektif. Dan juga usaha untuk meningkatkan komitmen organisasi karyawan pada perusahaan bisa melalui pengembangan kualitas kehidupan kerja, salah satu caranya adalah dengan memberikan kesempatan bagi karyawan untuk mengembangkan diri melalui program pelatihan dan berpartisipasi dalam setiap pengambilan keputusan yang berhubungan dengan pekerjaan mereka.

Hasil uji pengaruh ketiga dimensi dari komitmen organisasi yaitu affective organizational commitment, continuance organizational commitment dan normative organizational commitment terhadap perilaku kerja inovatif. mendukung penelitian dari Vermeulen (2004), Setiawan (2018) dan Prayudhayanti (2014) yang mana menyimpulkan adanya pengaruh signifikan antara komitmen organisasi dengan perilaku kerja inovatif karyawan, yang berarti jika karyawan memiliki komitmen organisasi yang tinggi maka akan memiliki perilaku kerja inovatif yang tinggi juga.

Dalam analisa yang dilakukan pada penelitian ini juga melakukan uji mediasi yang dilakukan oleh ketiga dimensi dari komitmen organisasi yaitu affective organizational commitment, continuance organizational commitment dan normative organizational commitment pada pengaruh QWL terhadap perilaku kerja inovatif dengan metode analisis PROCESS by Andrew F. Hayes. Pada uji tersebut menghasilkan pengaruh diantara variabel tersebut sebesar 0,3166 dengan interval kepercayaan (Confidence Interval) 95\% dari hasil bootsrap berkisar antara BootLLICI (Lower level for CI) sebesar 0,1449 sampai BootULCI (upper level for CI) sebesar 0,5281. Berdasarkan data tersebut dapat dikatakan bahwa komitmen organisasi secara simultan dapat memediasi pengaruh antara QWL terhadap perilaku kerja inovatif pada karyawan.

Hasil tersebut mendukung penelitian yang dilakukan oleh Elshifa dkk., (2020) yang menghasilkan bahwa adanya pengaruh antara QWL terhadap perilaku kerja inovatif denfgan menggunakan komitmen organisasi sebagai variabel mediasi. Dengan penambahan variabel komitmen organisasi secara simultan sebagai mediasi pada pengaruh antara QWL terhadap perilaku kerja inovatif dapat menjadi penghubung secara tidak langsung. Efek mediasi dari variabel komitmen organisasi nantinya akan berkontribusi untuk meningkatkan munculnya perilaku kerja inovatif pada karyawan, sehingga dalam penerapannya karyawan dan perusahaan dapat memperhatikan faktor QWL, affective organizational commitment, continuance organizational commitment dan normative organizational commitment dengan tujuan menguntungkan pribadi, kelompok maupun organisasi berbentuk pengembangan ide atau teknologi baru yang lebih efisien. Artinya analisis ini menghasilkan bahwa karyawan yang memiliki QWL tinggi akan meningkatkan perilaku kerja inovatif melalui komitmen organisasi yang menjembatani secara tidak langsung hubungan diantara keduanya.

Dari hasil tersebut dapat mencerminkan bahwa dengan peningkatan kualitas kehidupan kerja yang dilakukan oleh karyawan melalui peningkatan partisipasi, penyelesaian konflik dan perbaikan komunikasi dibarengi dengan pemberian fasilitas keselamatan kerja, keamanan kerja, pemberian kompensasi yang layak, peningkatan prestasi perusahaan dan memberikan kesempatan berkarir yang dilakukan oleh perusahaan akan meningkatkan komitmen karyawan, sehingga karyawan dapat memunculkan, mengenalkan dan menerapkan ide atau gagasan baru yang berdampak pribadi, 
kelompok maupun perusahaan secara umum. Hal tersebut dapat menjawab tantangan terkait peningkatan inovasi pada perusahaan.

Dalam analisis jalur menghasilkan hubungan negatif dan tidak signifikan pada jalur $\mathrm{f}$, jalur tersebut menghubungkan antara (CC) dengan perilaku kerja inovatif. Hal tersebut menolak studi yang telah dilakukan oleh Setiawan (2018) yang menyatakan bahwa adanya hubungan positif dan signifikan antara dimensi komitmen afektif, komitmen kontinuan dan komitmen normatif bernilai signifikan terhadap perilaku kerja inovatif. Meyer dkk., (1998) dalam laporannya menyebutkan bahwa adanya korelasi antara pengalaman dan pengetahuan karyawan terkait dengan perusahaanya terhadap dimensi ac dan nc, dimana karyawan setidaknya telah berada pada perusahaan yang sama selama 6 sampai 12 bulan atau lebih, namun hasil berbeda ditemukan pada dimensi cc yang mana tidak ada korelasi dengan pengalaman dan pengetahuan ttg perusahaannya. Berdasarkan data karakteristik yang ada, responden pada penelitian ini sebanyak 63,08\% atau 82 orang memiliki masa kerja 12 bulan atau lebih pada perusahaan yang sama, sehingga hasil tersebut memungkinkan terjadi.

\section{S I M P U L A N}

Penelitian ini menyimpulkan bahwa adanya pengaruh signifikan QWL terhadap perilaku kerja inovatif $\mathrm{H}_{1}$ diterima, adanya pengaruh QWL terhadap affective organizational commitment, continuance organizational commitment dan normative organizational commitment (Komitmen organisasi) $\mathrm{H}_{2}$ diterima, adanya pengaruh signifikan antara affective organizational commitment, continuance organizational commitment dan normative organizational commitment (komitmen organisasi) terhadap perilaku kerja inovatif dan adanya pengaruh signifikan antara QWL terhadap perilaku kerja inovatif dengan komitmen organisasi sebagai variabel mediasi pada karyawan.

Peneliti memberikan saran pada penelitian selanjutnya agar menambahkan kategori dalam penentuan partisipan yaitu karyawan yang telah bekerja lebih dari 1 tahun pada perusahaan yang sama. Peneliti juga memberikan saran kepada perusahaan agar memperhatikan kualitas kehidupan kerja karyawannya dengan memberikan jaminan kesehatan, keselamatan dan keamanan kerja, pemberian kompensasi yang layak, meningkatkan prestasi perusahaan dan memberikan kesempatan pengembangan karir. Peneliti memberikan saran kepada karyawan agar meningkatkan komitmen organisasi dengan melibatkan diri dengan perusahaan, bekerja pada perusahaan yang sama dan berkontribusi pada perusahaan dan yang terakhir adalah menyadari bahwa perusahaan telah memberikan fasilitas sehingga memiliki perasaan wajib untuk bertahan.

\section{U C A P A N T E R I MAKASIH}

Ucapan terima kasih diucapkan peneliti kepada tuhan yang maha esa, pihak kampus yang terlibat, keluarga serta seluruh rekanan peneliti yang membantu dalam pengerjaan naskah, selain itu juga kepada seluruh partisipan yang telah mengisi kuesioner penelitian ini.

\section{DEKLARASI POTENSI TERJADINYA KONFLIK KEPENTINGAN}

Muhammad Rio Bagus Ilmawan dan Fajrianthi tidak bekerja, tidak berafiliasi dengan perusahaan, membuka jasa konsultasi, memiliki seluruh atau sebagaian saham perusahaan, artau menerima dana dari instansi/organisasi/perusahaan manapun yang berpotensi mendapatkan keuntungan dari penelitian yang telah dilakukan.

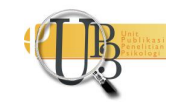




\section{P USTAKA ACUAN}

Abstein, A., Heidenreich, S., \& Spieth, P. (2014). Innovative Work Behaviour: The Impact of Comprehensive HR System Perceptions and the Role of Work-Life Conflict. Industry and Innovation, 21(2), 91-116. https://doi.org/10.1080/13662716.2014.896159

Allen, \& Meyer. (1996). Affective, Continuance, and Normative Commitment to the Organization: An Examination of Construct Validity. Journal of Vocational Behavior, 49(3), p252.

Ariani, D. (2017). Pengaruh Quality of Work Life dan Budaya Kaizen Terhadap Komitmen Organisasi Melalui Kepuasan Kerja Sebagai Variabel Intervening di Bank Syariah Mandiri .... http://erepository.perpus.iainsalatiga.ac.id/id/eprint/7737

Arifin, N. (2001). Analisis kualitas kehidupan kerja, kinerja, dan kepuasan kerja pada cv. duta senenan jepara. 11-21.

Azwar, S. (2012). Penyusunan Skala Psikologi. Pustaka Pelajar.

Baron, R. M., \& Kenny, D. A. (1986). The Moderator-Mediator Variable Distinction in Social Psychological Research: Conceptual, Strategic, and Statistical Considerations. Journal of Personality and Social Psychology, 51(6), 1173-1182. https://doi.org/10.1007/BF02512353

De Jong, J., \& Den Hartog, D. (2010). Measuring innovative work behaviour. Creativity and Innovation Management, 19(1), 23-36. https://doi.org/10.1111/j.1467-8691.2010.00547.x

Elshifa, A., Dwi Anjarini, A., \& Jamaludin Kharis, A. (2020). PENGARUH QUALITY OF WORK LIFE DAN PENGGUNAAN TEKNOLOGI INFORMASI TERHADAP PERILAKU KERJA INOVATIF DOSEN YANG DIMEDIASI KOMITMEN ORGANISASI (Studi pada Dosen Politeknik Pusmanu Pekalongan). Economicus, 13(2), 189-200. https://doi.org/10.47860/economicus.v13i2.177

Kleysen, F. ., \& Street, C. T. (2001). Toward a multi-dimensional measure of individual innovative behavior. Journal of Intellectual Capital, 2(3), 284-296. http://dx.doi.org/10.1108/EUM0000000005660

Korzilius, H., Bücker, J. J. L. E., \& Beerlage, S. (2017). Multiculturalism and innovative work behavior: The mediating role of cultural intelligence. International Journal of Intercultural Relations, 56, 13-24. https://doi.org/10.1016/j.ijintrel.2016.11.001

Meyer, J. P., Irving, P. G., \& Allen, N. J. (1998). Examination of the combined effects of work values and early work experiences on organizational commitment. Journal of Organizational Behavior, 19(1), 29-52. https://doi.org/10.1002/(SICI)1099-1379(199801)19:1<29::AID-J0B818>3.0.CO;2-U

Natasha. (2017). Komitmen organisasi.

Neuman, W. L. (2006). Social Research Methods: Qualitative and Quantitative Approaches. In Teaching Sociology (Vol. 30, Issue 3). https://doi.org/10.2307/3211488 
Nurcholisyah. (2007). Hubungan antara quality of working life dengan komitmen organisasi pada karyawan PT.Telekomunikasi selular grapari yogyakarta.

Octavia, A., \& Ratnaningsih, I. Z. (2017). Dengan Perilaku Inovatif Karyawan Non Proses ( Supporting) PT Indocement Tunggal Prakarsa Tbk Plant Palimanan. Jurnal Empati, 6(1), 40-44.

Parvar, M. R. F., Allameh, S. M., \& Ansari, R. (2013). Effect of Quality of Work Life on Organizational Commitment by SEM. International Journal of Academic Research in Business and Social Sciences, $3(10), 135-144$.

Prayudhayanti, B. N. (2014). Peningkatan Perilaku Inovatif Melalui Budaya Organisasi. Jurnal Ekobis, 15(2), 19-32.

Setiawan, L. A. R. (2018). Hubungan Antara Komitmen Organisasi Dan Perilaku Inovatif Pada Karyawan Bank. 1-15.

Syafrudin. (2013). PENGARUH WORK LIFE QUALITY TERHADAP KOMITMEN ORGANISASI DENGAN KEPUASAN KERJA SEBAGAI VARIABEL INTERVENING. Perpustakaan Unair.

Varma, Aparna J., Kotresh Patil, and R. S. . (2018). Influence of Quality of Worklife on Organization Commitment. Journal of Emerging Technologies and Innovative Research (JETIR), 5(8), 834-841.

Vermeulen, P. (2004). Managing product innovation in financial services firms. European Management Journal, 22(1), 43-50. https://doi.org/10.1016/j.emj.2003.11.012

Warhurst, C., Mathieu, C., \& Wright, S. (2017). Workplace Innovation and the Quality of Working Life in an Age of Uberisation. 245-259. https://doi.org/10.1007/978-3-319-56333-6_15

Zin, R. M. (2004). Perception of Professional Engineers toward Quality of Worklife and Organizational Commitment: A Case Study. Gadjah Mada International Journal of Business, 6(3), 323. https://doi.org/10.22146/gamaijb.5553 